\title{
A Critical Review of Listening Comprehension in Interpreter Training: The Case of Spanish Translation and Interpreting Degrees
}

\author{
EnRiQue Cerezo Herrero \\ Universidad CEU Cardenal Herrera
}

Received: 2 September 2015 / Accepted: 17 February 2017

ISSN: 1697-7467

\begin{abstract}
This article purports to study from a theoretical viewpoint the use of traditional listening comprehension exercises, namely, multiple-choice, gap-filling, etc., in interpreter training. For that purpose, we will first establish through a brief analysis of the main official foreign language English exams the typology of exercises most utilized in these proficiency tests and their main pedagogical principles. Secondly, we will focus on the general and specific difficulties that the development of this linguistic skill presents in interpreter training. In accordance with this comparative study, we will establish a set of items which differ from the oral comprehension principles that govern the professional activity of an interpreter.
\end{abstract}

Keywords: listening comprehension, foreign language teaching, interpreter training, cognitive processes.

La comprensión oral para la formación de intérpretes en las asignaturas de lengua extranjera: una revisión crítica

RESUMEN: El presente artículo tiene como objetivo estudiar desde una perspectiva teórica el uso de ejercicios tradicionales de comprensión oral, a saber, ejercicios de elección múltiple, de rellenar huecos, etc., en la formación de intérpretes. Para ello, en primer lugar se establecerá mediante un breve análisis de los principales exámenes oficiales de inglés como lengua extranjera la tipología de ejercicios más utilizada en estas pruebas de aptitud y sus principales principios pedagógicos. En segundo lugar, nos centraremos en las dificultades generales y específicas que el desarrollo de esta destreza lingüística presenta en la formación de intérpretes. A tenor de este estudio comparativo, estableceremos una serie de puntos que difieren de los principios de comprensión oral que gobiernan la actividad profesional de un intérprete.

Palabras clave: comprensión oral, enseñanza de lenguas extranjeras, formación de intérpretes, procesos cognitivos.

\section{INTRODUCTION}

Listening comprehension (hereinafter LC) is a communicative skill which has gained considerable importance in the teaching of foreign and second languages. As Wilcox (2001: 87) so aptly puts it, "it is the most direct connection to meaning in the language." Scholars 
such as Rivers (1981), Feyten (1991), Oxford (1993), Mendelsohn (1994) and Burley-Allen (1995) stress that it is the language skill that we use the most in our everyday lives (between 40-50\%). However, this linguistic ability has unjustifiably been downgraded and regarded as the poor sister of reading comprehension, despite the fact that both skills are at variance when it comes to decodification processes. As a result, there seems to be a bibliographic void when it comes to second language listening comprehension (Kurita, 2012). According to Vandergrift (2007: 191), this inattention could be attributed to the following:

Its implicit nature.

The ephemeral nature of the acoustic input.

The difficulty in accessing the underlying processes that shape this linguistic skill.

It could be argued that these attributes have led LC to be considered as the most neglected skill in foreign language learning, as well as the most difficult one to teach since the teacher cannot take part in the development of the activity, but just give students some tips on how to conduct this activity efficiently.

It was not until the 1990s when it was regarded as an essential skill in the learning of foreign and second languages (Vandergrift, 1999: 168). This was primarily due, on the one hand, to the development of more communicate methodologies and the technological advances which grant access to an unlimited number of multimedia resources and, on the other hand, to the great progress made in oral communication (Rost, 2006: 48).

In spite of the importance of this skill in foreign language learning nowadays, neither the research into the didactics of foreign languages nor the translation theories have tackled the complexity of LC in translation programs, leaving unanswered questions such as how this language skill should be implemented in foreign language subjects when the goal is to train interpreters. Due to this lack of research, lecturers usually resort to general language teaching textbooks in which more traditional types of listening activities can be found, namely, multiple-choice, gap filling, true and false, etc. (Cerezo, 2013). However, we are of the opinion that interpreter trainees have to develop their listening skill in accordance with the needs of their future profession, dealing with the various cognitive processes that differentiate the type of listening that interpreters use from other forms of listening. On this basis, there are many questions that spring to mind: Do traditional LC exercises cater for the needs of the students? Are they suitable for interpreter training? How should LC be fostered in a Translation program? These are some of the questions that we will try to answer in this paper.

\section{Typology OF THE MOST COMMON TRADITIONAL LC EXERCISES}

In general, LC is a language skill that is indirectly assessed with the use of other linguistic skills, e.g. reading, writing, etc. The aim of this assessment is to find out what the oral comprehension level of the student is in a given language. We will consider the type of activities most commonly employed in official English as a foreign language exams. English is the language most students choose as their first language, or language B. In addition, close scrutiny of different syllabi published by different Translation departments has led us to the conclusion that these typology of exercises is generally the most commonly used when the 
goal is to enhance the listening comprehension skill in English language lessons in Spanish Translation and Interpreting faculties.

The exams that we have reviewed for this study are the following: FCE (First Certificate in English); CAE (Cambridge Advanced English); CPE (Certificate of Proficiency in English); BEC Vantage and BEC Higher (Business English Certificates); ICFE (International Certificate in Financial English) and ILEC (International Legal English Certificate). All of these exams correspond to B2, C1 and C2 levels according to the Common European Framework of Reference for Languages (CEFR). This is due to the fact that most Spanish universities require their students to have a B2 level to access Translation and Interpreting studies. We have also considered the MSUELT (Michigan State University English Language Test); IELTS (International English Language Testing System); TOEFL (Test of English as a Foreign Language) and TOEIC (Test of English for International Communication). All the listening tests that make up these exams include four parts with one exercise each, with the exception of BEC Vantage and Higher, MSUELT and TOEFL.

Table 1. Official English exams: level and typology of LC activities

\begin{tabular}{|c|c|c|c|c|c|}
\hline & LEVEL & PART 1 & PART 2 & PART 3 & PART 4 \\
\hline FCE & B2 & Multiple choice & $\begin{array}{c}\text { Sentence com- } \\
\text { pletion }\end{array}$ & $\begin{array}{l}\text { Multiple } \\
\text { matching }\end{array}$ & Multiple choice \\
\hline CAE & $\mathrm{C} 1$ & Multiple choice & $\begin{array}{c}\text { Sentence com- } \\
\text { pletion }\end{array}$ & $\begin{array}{l}\text { Multiple } \\
\text { choice }\end{array}$ & Multiple matching \\
\hline $\mathrm{CPE}$ & $\mathrm{C} 2$ & Multiple choice & $\begin{array}{l}\text { Sentence com- } \\
\text { pletion }\end{array}$ & $\begin{array}{c}\text { Multiple } \\
\text { choice }\end{array}$ & Multiple matching \\
\hline BEC Vantage & $\mathrm{B} 2$ & Note completion & $\begin{array}{l}\text { Matching } \\
\text { exercise }\end{array}$ & $\begin{array}{l}\text { Multiple } \\
\text { choice }\end{array}$ & $* * *$ \\
\hline BEC Higher & $\mathrm{C} 1$ & Note completion & $\begin{array}{l}\text { Matching } \\
\text { exercise }\end{array}$ & $\begin{array}{l}\text { Multiple } \\
\text { choice }\end{array}$ & $* * *$ \\
\hline ICFE & $\mathrm{C} 1$ & Multiple choice & $\begin{array}{l}\text { Multiple } \\
\text { choice }\end{array}$ & $\begin{array}{c}\text { Sentence } \\
\text { completion }\end{array}$ & Multiple matching \\
\hline ILEC & $\mathrm{C} 1$ & Multiple choice & $\begin{array}{l}\text { Multiple } \\
\text { choice }\end{array}$ & $\begin{array}{c}\text { Sentence } \\
\text { completion }\end{array}$ & Multiple matching \\
\hline MSUELT & $\begin{array}{c}\text { Profi- } \\
\text { ciency } \\
\text { Test }\end{array}$ & Multiple choice & $\begin{array}{l}\text { Multiple } \\
\text { choice }\end{array}$ & $* * *$ & $* * *$ \\
\hline IELTS & $\begin{array}{c}\text { Level } \\
\text { Test }\end{array}$ & \multicolumn{4}{|c|}{$\begin{array}{l}\text { The exam is made up of } 4 \text { different sections which can vary in exercise } \\
\text { format. Types: (1) Multiple choice; (2) Matching exercise; (3) Plan, map and } \\
\text { diagram labeling; (4) Form, note, table, flowchart and summary completion; } \\
\text { (5) Sentence completion; (6) Short-answer questions. }\end{array}$} \\
\hline TOEFL & $\begin{array}{c}\text { Level } \\
\text { Test } \\
\end{array}$ & Multiple choice & $\begin{array}{l}\text { Multiple } \\
\text { choice }\end{array}$ & $* * *$ & $* * *$ \\
\hline TOEIC & $\begin{array}{c}\text { Level } \\
\text { Test }\end{array}$ & Multiple choice & $\begin{array}{l}\text { Multiple } \\
\text { choice }\end{array}$ & $\begin{array}{l}\text { Multiple } \\
\text { choice }\end{array}$ & Multiple choice \\
\hline
\end{tabular}


As Table 1 shows, multiple choice and sentence completion activities are the most common LC activities in official English exams these days, followed by matching exercises.

Multiple choice activities can be evaluated quickly and assessment is objective. Each question includes three or four possible answers, only one of them being correct. The other incorrect items are known as distractors. These usually include words or details which are normally mentioned in the recording but which are incorrect. The problem with this type of activity lies in the fact that it is not always possible to incorporate plausible distractors in the items and, as a result, certain parts of the recording cannot be assessed. For this reason, a thorough comprehension of the speech cannot always be guaranteed (Thompson, 1995: 43). Assessment is based on the comprehension of more specific details, rather than on general understanding. In addition, approximately two thirds of the correct options are generally the longest statements. If in doubt, this could help listeners decide on the most suitable answer (Ur, 1984: 137).

Sentence completion activities is the second most preferred type of listening activities in official English exams. These activities comprise a series of sentences with some blank gaps which have to be filled in according to what the speaker says. The length of the sentences, which the oral text does not reproduce literally, varies depending on the information required, but as a rule in higher levels sentences are longer than in lower levels. Evaluation is objective too, as it is based on the number of gaps the listener is able to fill in. Generally speaking, the listener has to understand the exact word or words used by the speaker to fill in the gaps. The problem with this type of listening is that what is actually being assessed is the ability to recognize words and not comprehension per se (Buck, 2001: 73). In addition, it is also possible to fill in the gaps without having actually understood the recording and answer some of them correctly.

Although less frequently used, some of the exams also include matching activities. Listeners are presented with a series of ideas or statements (usually more than they need) which they must link to different excerpts. Again, the drawback is that the evaluation is limited to specific information and it might also be possible to match the statements with the excerpts at random and answer some of them correctly. What is more, it might even be difficult to ensure partial understanding. Comprehension of some specific words or sentences could be sufficient to match the statements.

\section{LISTENING COMPREHENSION IN TRANSLATION AND INTERPRETING STUDIES}

LC is undoubtedly a complex skill through which speakers update their knowledge of the language both internally and in situ. All semantic, syntactical, phonological and lexical knowledge that students possess converge to give rise to an encoded message concealed beneath a sequence of words. This process turns to be even more complicated if, as in the case of interpreting, the listening activity requires attention sharing among different cognitive processes. From a translatology viewpoint, oral comprehension for interpreting could be defined as follows:

La captación inmediata del sentido del discurso oral, lo cual implica el reconocimiento de los rasgos fonológicos, morfosintácticos y suprasegmentales de la lengua desde la que se traduce; el reconocimiento y diferenciación inmediata de las distintas 
funciones comunicativas, usos (campo, modo y tenor) y usuarios (dialectos geográficos, etc.). (Jiménez Ivars, 1999: 52).

The teaching of LC in foreign language subjects in Translation and Interpreting programs should chiefly aim to train students in oral comprehension for interpreting. Oral comprehension is the first step in oral translation. It is therefore the basis for the training of interpreters (Blasco, 2007: 141). As a matter of fact, the problems that most interpreters usually encounter originate from the oral perception of the stimulus, namely, a very technical terminology, unknown accents, rapid speaking pace, etc. Nevertheless, as we have already mentioned, this skill unfortunately receives little, if any, attention in the training of interpreters (Cerezo, 2013; Blasco, 2007). LC for interpreting is normally fostered through traditional listening activities whose aims do not seem to be in keeping with those required in the training of interpreters and, consequently, the professional needs of the students are not prioritized.

\subsection{General difficulties}

As a rule, one of the major obstacles to effective LC training is to put this skill on a level with reading comprehension for both of them being receptive in nature (Eastman, 1991). Most students tend to mentally translate every word uttered so as to understand the message conveyed. They oftentimes employ similar comprehension strategies for both skills, disregarding the fact that in written comprehension, as opposed to oral comprehension, they can access the written text as many times as they deem necessary. In addition, this learning tendency takes no account of the fact that in oral comprehension sounds are interwoven in speech and, consequently, it is difficult to distinguish the confines amongst them (Renandya and Farrel, 2011: 53). English, for instance, is a time-stressed language. It is estimated that stressed syllables are three times longer than non-stressed syllables, which can barely be heard. This phenomenon, known as allomorphic variation, may occur due to the following reasons (Rost, 1994):

Assimilation processes: when sounds pertaining to different words merge, e.g. wonchoo instead of won't you.

Reduction processes: when sounds are shortened, e.g. gonna instead of going to.

Elision processes: sounds which are not pronounced due to a rapid articulation,

e.g. nexday instead of next day.

Buck (2001: 33) adds an additional process known as intrusion to refer to alien sounds that accompany words, e.g. in British English, the final $r$ in words such as car or star is not usually pronounced, with the exception of when it is followed by a vowel, e.g. far away, in which case the $r$ is voiced.

In a mother tongue, it is generally easier to automatically access the meaning of words. The LC process in a native language does not consume the whole attention span, allowing the listener to do the following:

Anticipate what the speaker is going to say by applying previous knowledge. 
Infer meaning through ellipsis, inadequate expressions or background noise.

Observe facial expressions and body language closely.

Infer the speaker's attitude or stance on the topic.

However, contrary to L1, the lack of familiarity with the syntactical, semantic and phonological aspects of the L2 narrows down the comprehension capacity. As a result, conjuring up an image of the message being conveyed takes up much processing capacity. If meaning cannot be accessed automatically, the cognitive system overloads and the comprehension process breaks up. It is therefore a skill that "seems to develop easily for mother-tongue listening, but requires considerable effort when listening in a foreign language is concerned" (Underwood, 1989).

Short-term memory, which is responsible for chunking the discourse so that the information can be interpreted and sent on to the long-term memory, also seems to be constrained in L2 oral comprehension. When listening to a foreign language, students seem unable to retain long chunks of discourse for a long time. What is more, when they do, what they normally get is a blurred picture of the message, which makes it harder to see further than the words themselves.

In the same vein, anxiety and stress also appear to be a stumbling block to the development of LC, as the attention span is more often than not hindered by these two elements. This could be due to various reasons. In a study conducted with 140 participants registered for the first three semesters of university-level Spanish courses, Jones (1998) established four driving forces for anxiety:

Characteristics of input: nature of the speech, level of difficulty, lack of clarity, lack of visual support or lack of repetition.

Process-related aspects: inappropriate strategies, lack of processing time, impossibility of studying LC or checking answers.

Anxiety associated with instructional factors: lack of LC practice, the pressure of tests or uncomfortable environment.

Personal attributes of teacher and learner.

As already noted, we cannot lose sight of the fact that LC is a language skill that cannot be taught, as the teacher cannot partake in the listening process. The teacher can basically provide the students with plenty of opportunities for practice (Eastman, 1991: 53). The ephemeral nature that LC presents only allows for the implementation of inference strategies and abilities in decision making in order that the students may control the listening process in a more effective way (Vandergrift, 1999: 172).

Because of all these difficulties, it is a foregone conclusion that studies such as those carried out by Goh (2000) or Grahan (2006) emphasize that students tend to quickly forget what they listen to, do not recognize words they already know, understand the words but not the intention, etc. All these hurdles should be dealt with in the foreign language subjects prior to starting interpreting courses. This is in line with the study conducted by Blasco (2007) on oral comprehension for interpreter trainees at University Jaume I in Spain. This author admits to having to devote half of her consecutive interpreting classes to LC activities, as 
most of the students have difficulties in understanding oral language. As shown in the results, the effects of this practice proved beneficial. In the final test, the pilot group obtained a 7.1 grade $(71 \%)$, whilst the control group got a 4.9 grade $(49 \%)$. In a survey administered afterwards, the vast majority of the students deemed necessary to expand the training in LC in Translation and Interpreting programs through subjects devoted to enhancing oral comprehension, oral activities in small groups, or specific modules to prepare students for interpreting subjects, among others.

\subsection{Specific difficulties}

In addition to the aforementioned characteristics, which determine in general terms how much students are able to understand in a foreign language, there are some other specific aspects that need to be borne in mind when it comes to LC for interpreting.

LC has traditionally been regarded as a passive skill in the linguistic paradigms prior to Pragmatics, especially Structuralism (Alcaraz, 1993: 100). However, LC for interpreting must be understood as an active skill because of the great deal of cognitive and psychological processes that it encompasses (Meskill, 1996: 180). According to Madrid and McLaren (1995), the factors that categorize LC as an active skill are the following:

Listeners must constantly ask themselves why they are listening.

Only when the noises and silences the listener hears are processed can meaning be extracted from them.

Anticipation and remembering what has previously been said is necessary.

Listeners cannot control the speed or tone of voice of the utterance.

Anderson and Lynch (1988) also reject the conceptualization of LC as a passive skill. They consider it to be a listener-as-tape-recorder activity as most of the time it employs listening patterns which many listeners would never use in their daily lives. There is much more to listening than just hearing a sequence of words. These words must be interpreted within a context and the sounds must be processed in order to infer meaning. Vandergrift holds a similar view when claiming that:

Listening comprehension is anything but a passive activity. It is a complex, active process in which the listener must discriminate between sounds, understand vocabulary and grammatical structures, interpret stress and intonation, retain what was gathered in all of the above, and interpret it within the immediate as well as the larger sociocultural context of the utterance. Coordinating all of this involves a great deal of mental activity on the part of the listener. (Vandergrift, 1999: 168).

Gile (1992, 2009) also views it as important to have an active knowledge of the language. This has been illustrated through his Gravitational Model of Linguistic availability, which explains the mental availability of words for interpreters. 


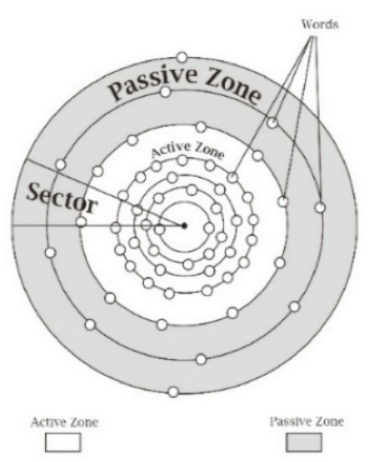

Fig. 1. The Gravitational Model of Linguistic availability (Gile, 2009)

According to this model, the circles which gravitate on orbits around the nucleus represent language constituents. ${ }^{1}$ The further these orbits ${ }^{2}$ are from the nucleus, the more processing capacity and time it takes to retrieve them for language use. Therefore, the orbits that surround the nucleus in the active zone are the language constituents that can be accessed easily and without much effort. Conversely, the orbits placed in the passive zone are the language constituents that can be understood but are not readily available for immediate comprehension or production (Gile, 2009). Therefore, the need to activate the foreign language is imperative if the aim is to carry out professional interpreting activities. Notwithstanding this, we are of the opinion that total activation of any foreign language is a far-reaching goal to be achieved and this is especially challenging if we take into consideration the pressure that interpreters are exposed to, as well as the use of specialized languages, which are commonly used in conferences. Drawing on the Gravitational Model, Faber and Jiménez Hurtado point out that:

Es necesario que un intérprete tenga suficientes palabras tanto en la Zona Activa como en la Pasiva para comprender y producir textos en una conferencia. En lo que concierne a la lengua general, esta condición casi siempre se da. No obstante, los problemas surgen, sobre todo, cuando se trata de lenguas especializadas. Además, la interpretación simultánea se suele realizar bajo presión, y por esta razón, las palabras disponibles sólo están en la Parte de la Zona Activa más cercana al núcleo, dado que no hay tiempo para un procesamiento más profundo. (Faber and Jiménez Hurtado, 2004: 105).

In our view, the Gravitational Model of Linguistic availability put forward by Gile represents faithfully the reality that characterizes the interpreter's profession. An interpreter must be able to access instantaneously all their linguistic and cultural knowledge in the foreign language. Interpreters rarely have time to think of linguistic terms during the

\footnotetext{
${ }^{1}$ Natural languages are composed of the following constituents: lexical units, compositional rules of general (non-specialized) language, and rules of languages for special purposes (Gile, 2009).

${ }^{2}$ The Orbits represent the distribution of language constituents in the mind.
} 
interpreting task. Words in the L2 must be easily recognized. In order to achieve this aim, the language constituents should be placed as close as possible to the nucleus. Distance thereof would result in:

A mental overload for the interpreter.

A tendency to make mistakes in the L1 re-expression stage, probably because of mental fatigue.

Anxiety due to failure to fully understand the message.

Gile $(1992,2009)$ also designed an Effort Model to make students aware of the intrinsic difficulties of Consecutive and Simultaneous Interpreting. The aim was to help students develop their own strategies so that they could tackle the difficulties that come up throughout the whole interpreting process. According to this theory, the processing capacity of an interpreter comprises different efforts:

$\mathrm{L}=$ Listening and analysis of the message in the source language.

$\mathrm{M}=$ Short term memory.

$\mathrm{P}=$ Production in the target language

$\mathrm{C}=$ Coordination of the above.

$$
\text { Interpreting process }=\mathrm{L}+\mathrm{M}+\mathrm{P}+\mathrm{C}
$$

The total sum of all four efforts constitutes the process followed by interpreters. None of these efforts must exceed the total processing capacity of the interpreter. Failure to do so will result in the disruption of the whole process. Hence, the importance of coordination to render a faithful oral translation of the original text.

Iglesias (2007: 127), taking as a reference Conference Interpreting, also explains that all the cognitive processes that take place during the interpreting task must be coordinated. In the case of Simultaneous Interpreting, if the interpreter only focused on the listening and analysis stage but failed to retain the information in his short term memory, the final production stage in L1 would be hampered by a number of mistakes of different nature, namely false senses, contradictions, senseless sentences, etc. This could be exemplified through the following illustration:
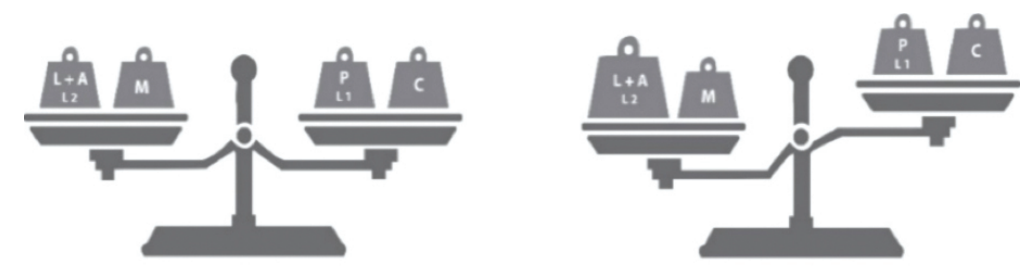

Fig. 2. Distribution of efforts in Simultaneous Interpreting 3 (Own elaboration)

\footnotetext{
${ }^{3} \mathrm{~L}+\mathrm{A}=$ Listening and analysis in $\mathrm{L} 2 ; \mathrm{M}=$ Memory; $\mathrm{P}=$ Production in $\mathrm{L} 1 ; \mathrm{C}=$ Coordination.
} 
As can be seen on the left scales, when all cognitive processes are coordinated, the scales are balanced. All of them have the same weight, implying that equal attention is given to all the efforts involved. However, too much focus on the Language and Analysis ( + +A) process, which is typical when training starts, would tip the balance sideways. In the case of Consecutive Interpreting, we encounter a very similar problem.
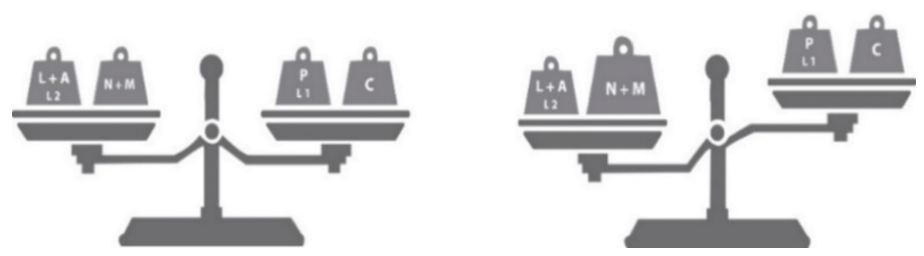

Fig. 3. Distribution of efforts in Consecutive Interpreting 4 (Own elaboration)

In the first phase, the interpreter cannot focus solely on note-taking as this would take up much of his processing capacity, rendering him incapable of balancing all the cognitive processes. As stated by Santamaría (2015: 19), «los estudiantes se concentran en exceso en la toma de notas y en consecuencia "se olvidan" de escuchar.» Additionally, not everything mentioned by the speaker can be noted down. That is the reason why the interpreter must rely on his short term memory to retrieve part of the information and make sense of what they jotted down. However, we must keep in mind that the amount of information a learner can hold in their memory is determined by their level of language proficiency (Vandergrift and Goh, 2015), therefore this capacity must be fully developed in the L2. As in Simultaneous Interpreting, failure to coordinate all the efforts will disrupt the delivery of the message in L1. In Consecutive Interpreting, coordination in the Language and Analysis (L+A) and Notes and Memory $(\mathrm{N}+\mathrm{M})$ stages is paramount, as nothing can be noted down or memorized if it is not previously understood.

The overlapping of all these cognitive processes and the need to balance them leads us to question the effectiveness of traditional LC activities when it comes to training interpreters since they do not seem to take into account professional interpreting practice.

\section{The Problem of General LC ACTIVITIES FOR INTERPRETER TRAining}

After a brief analysis of the most common LC exercises used in general foreign language teaching and the demands that characterize LC for interpreting, we will now explain why general LC activities are not, in our opinion, the best option to train interpreters and, therefore, why it is of prime importance to design activities that set realistic goals and objectives according to the very specific needs of this group of future professionals.

\footnotetext{
${ }^{4} \mathrm{~L}+\mathrm{A}=$ Listening and analysis; $\mathrm{N}+\mathrm{M}=$ Note-taking and memory; $\mathrm{P}=$ Production; $\mathrm{C}=$ Coordination
} 


\subsection{Active vs. selective listening}

The type of listening employed by the interpreter will be paramount for the successful implementation of the interpreting task. According to Iliescu (2004: 44), LC for interpreting "ha de ser diferente de la que cualquier receptor pueda realizar en situaciones diarias de comunicación interpersonal." Generally speaking, traditional LC activities are based on a type of selective listening. Listeners usually focus on understanding the information required to answer the comprehension questions, turning a deaf ear to all the superfluous details. They just scan the material for certain information (Douglas and Lee, 2015). Listeners therefore apply what Mendelsohn (1994) has named rejection strategies. They indirectly just listen to the speech or conversation awaiting to hear the information that they need to complete the activity and do not strive to fully understand the whole speech. Despite there usually being distractors for the activity to be more challenging, just understanding isolated sentences will usually allow the listener to find the answers, since the questions utilized to check whether the student has understood the information require partial understanding, e.g. specific information, words or short phrases, a date, a number, etc. Therefore, through these activities, we cannot ensure whether the listener's understanding will be enough to conduct interpreting tasks. Traditional LC exercises do not contemplate the very specific features that govern the kind of comprehension that interpreters put into practice and, as such, they do not seem the best option to train prospective interpreters.

LC for interpreting should be based on the principle of active listening (Santamaría, 2015: 19). The text must be taken as a whole. All the elements that make it up are interrelated and only make sense when they are interpreted within the text and context. This type of listening makes the difference between hearing and listening. The comprehension mechanisms activated must allow the listener to see further than just the meaning of words. In addition to applying both bottom-up and top-down processing so that listening becomes automatic (Vandergrift and Goh, 2015: 18), the listener must show a great deal of interest in what is being said and stay alert all the time while paying attention to the speaker's whole communication: and decoding the message through both the verbal and nonverbal aspects of the communication act. This is what Burley-Allen (1995: 14) has called empathetic listening, which involves listening from the heart, allowing understanding, caring, and empathy to set in. The listener should place himself or herself in the speaker's shoes and see things from his or her own perspective. This sort of listening also implies taking into consideration non-verbal communication, as well as the speaker's thoughts and feelings. Easy as it may seem, this type of listening does not come naturally, especially in a second language, because much working capacity is consumed just trying to understand the message. Hence, this type of listening calls for utter concentration.

A few people seem to be capable of concentrated and focused listening for long periods of time but many of us are not, particularly when listening to a second language where so much available processing capacity is taken up by basic requirements like chunking the discourse into comprehensible phrases and trying to identify the most significant words. (Brown, 2008: 11). 
In addition, it cannot be neglected that this form of listening requires a previous training period, as it is not a natural ability that listeners possess. According to Psychology, everyday listening is selective by nature. The listener only retains the information that he or she deems necessary or important based on his or her own criteria or beliefs. But interpreters have to fully convey the message that is delivered and this can only be attained through extensive training (Nolan, 2005). In the case of Consecutive Interpreting, Jones refers to this training need in the following way:

This form of listening is not a natural gift; it is something that has to be learned and trained. Even when it has been learned it requires great powers of concentration and stamina in any but the shortest of meetings held in consecutive, hence the need for interpreters to be fit and mentally alert. (Jones, 1998: 16).

\subsection{Different cognitive processes}

It is also important to emphasize that the cognitive process employed in traditional LC activities do not concur with those required for interpreting. In the following illustrations we show how these processes differ:

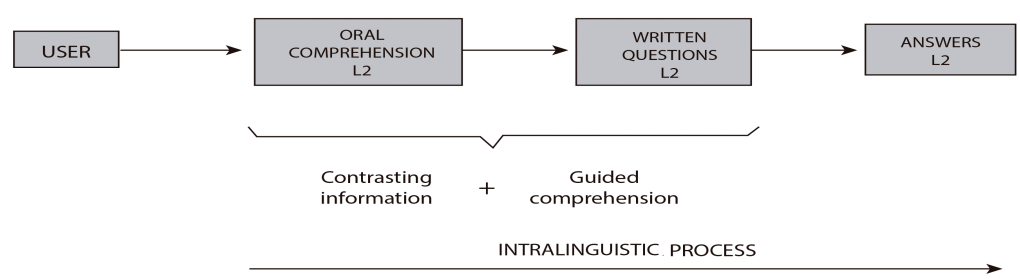

Fig. 4. LC general process (Own elaboration)

In general LC exercises, students usually have the questions that they need to answer in writing. These might give them an idea of how the recording is going to be organized. They can contrast what they understand with the written statements, which lead them to focus their attention on specific information. The written information guides the listener through the whole process, which takes place in just one linguistic code, that is, the L2.

Another negative aspect that traditional LC exercises present for interpreter training is that the excerpts utilized are usually too long to develop short term memory. The lack of non-verbal elements and information about the context in which the text is embedded is another major problem. Although some pre-listening activities are often included so as to provide the students with some previous knowledge, these are too general and usually focus on linguistic aspects, but rarely are the students given information about the speaker or their accent, although the latter could be due to the fact that traditional LC exercises generally use standard British and American accents. 
Also, assessment involves indirect methods, e.g. answering specific questions or carrying out certain tasks, or carrying out certain tasks that show comprehension of the message. Because of that, "listening scores will always be influenced by other skills required for task completion" (Buck, 1997: 66) and, consequently, the focus, in this case, is as much on interpreting the text as it is on listening comprehension" (Flowerdew and Miller, 2005: 47). In interpreting, as can be seen in the illustration below, the cognitive processes involved are at odds with those employed in general LC.

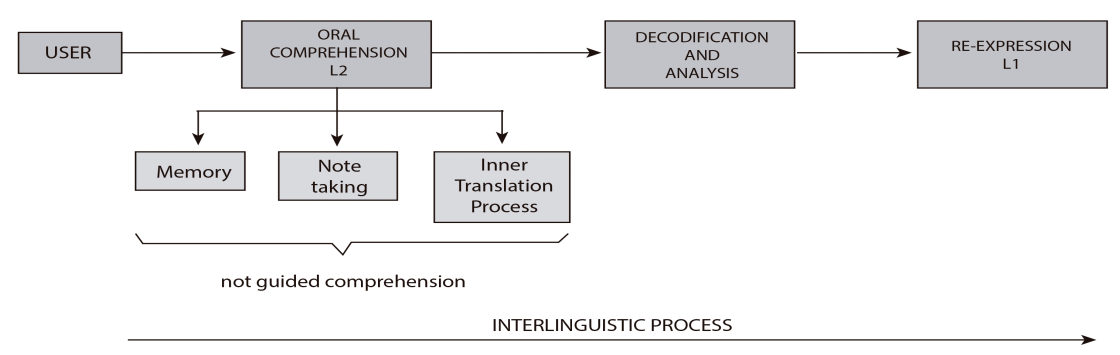

Fig. 5. LC for interpreting (Own elaboration)

Throughout the whole interpreting process, the students need to activate high demanding cognitive skills. As explained by Iglesias (2007), these must converge until the re-expression in L1 stage is reached. The teaching practice shows that the LC capacity is limited when the students begin their first interpreting courses because of the simultaneous cognitive and psychological processes that take place and the lack of ability to merge them together. Aside from memorizing chunks of information and making notes throughout the interpreting process (unless a transcript of the speech is provided in advance), most students also start an inner translation process to help them deliver the information in the target language. At the same time as the message is understood and new information comes up, it has to be decoded and analyzed. In contrast to general LC practice, all of these processes are unguided and the students solely rely on their own capacity to successfully travel along the continuum, which is interlinguistic by nature. LC for interpreting purposes should help the students develop their processing capacity. It should enhance their ability to listen and analyze the message, their short term memory, their ability to take notes and produce the message in a different language, as well as coordination of all the above (Gile, 1992, 2009).

\section{Conclusion}

This paper has outlined the importance of developing the LC skill in accordance with the professional needs of interpreters within Spanish Translation and Interpreting programs. LC is admittedly an essential communicative skill in human communication. Nevertheless, due to its complex nature and the difficulty in analyzing its main constituents from a 
rigorous and scientific viewpoint, this skill has often taken second place in research and, consequently, in foreign language teaching. Within Translation studies, the need to enhance this competence is even greater if we bear in mind that in the current teaching programs the number of credits devoted to interpreting courses has been narrowed down and, as a result, these courses must prize the acquisition of strategies and professional knowledge over the development of LC per se so that they do not turn into language enhancement courses.

Resulta paradójico que en un Grado de Traducción e Interpretación de 240 cr. los estudiantes solo deban superar 7,2 cr. ECTS de materias troncales de interpretación. Con ello, los nuevos títulos corren el serio riesgo de formar profesionales mediocres, que saben traducir solo a medias, pues no tienen conocimientos suficientes ni han desarrollado las competencias al nivel exigible en el mercado laboral. (Prieto, 2012: 258).

However, the current situation is a far cry from reality. The training students receive in Interpreting courses differs widely from one university to another (Martin, 2015: 106). This makes it difficult to establish a common basis for training students in LC. Additionally, most of the students cannot fully understand oral language and the interpreting courses become their worst enemies (Blasco, 2007). Therefore, there is an impending need for previous oral language comprehension enhancement for which we will need to adopt a specific methodology which grants students full access to the oral message and, consequently, helps them overcome the first stage of the interpretation process, that is, the comprehension stage. The main objective of oral comprehension in the first foreign language in Translation programs should be to provide students with the necessary linguistic tools to carry out professional interpretation tasks. For this purpose, it is imperative to activate the language in accordance with interpreting practice.

LC for interpreting should be developed taking into consideration that, as opposed to traditional LC activities, it requires active listening. Students must focus on everything mentioned in the speech and not on specific details because the oral translation rendered must be a complete and coherent version of the original text. Also, the cognitive processes that interpreters employ are specific to this professional field of expertise. Students must get used to retrieving information from their short term memory from the very beginning by using specific cognitive processes (note-taking, memorizing, analysis and decodification and re-expression in L1). Inability to coordinate all of these will distort the message in the re-expression stage.

The main limitation of this research lies in the fact that it is based on theoretical foundations which should ideally be supported by empirical data. That is why in future research, we aim to carry out an investigation with different groups of interpreter trainees in order to know their opinion regarding their previous training received in listening comprehension. There is also a need to develop a typology of activities that help students overcome the first interpreting stage according to the needs imposed by interpreting practice. However, as emphasized by Clouet (2010: 136), teaching and learning activities need to mirror real communicative situations that the students will have to deal with later on. Only through a professional focused training will students be able to develop the necessary competences that characterize interpreters. 
Listening comprehension for interpreting purposes is a field in urgent need of research. On the one hand, most students complain that the foreign language subjects do not prepare them for their interpretation subjects, therefore we cannot take for granted their advanced oral comprehension often alluded to in research. On the other hand, there is an impending need to develop didactic materials to suit the linguistic and professional needs of the students. General textbooks are not suitable for enhancing this skill, as the type of comprehension required differs greatly from the type of comprehension that interpreters use. This skill should be taught, then, taking into account the use that students will make of the language in their future profession.

\section{REFERENCES}

Alcaraz Varó, E. (1993). "La lingüística y la metodología didáctica de las lenguas extranjeras", in V. García Hoz (eds.), Enseñanza y aprendizaje de las lenguas modernas. Madrid: Ediciones Rialp, 19-108.

Anderson, A. and Lynch, T. (1988). Listening. Oxford, Oxford University Press.

Blasco Mayor, $\mathrm{M}^{\mathrm{a}} \mathrm{J}$. (2007). La comprensión oral en el desarrollo de la pericia de la interpretación de conferencias. Granada: Comares.

Buck, G. (1997). "The testing of listening in a second language”, in C.M. Claphan and D. Corson (eds.), Language testing and assessment. Encyclopedia of language and education. Vol. 7, Dordrecht: Kluwer.

Buck, G. (2001). Assessing Listening. Cambridge: Cambridge University Press.

Burley-Allen, M. (1995). Listening: the forgotten skill. New York: John Wiley \& Sons.

Cerezo Herero, E. (2013). La enseñanza del inglés como lengua B en la formación de traductores e intérpretes en España: la comprensión oral para la interpretación. Tesis Doctoral. Valencia: Universitat de València.

Clouet, R. (2010). Lengua inglesa aplicada a la traducción. Una propuesta curricular adaptada al espacio europeo de educación superior. Granada: Comares.

Douglas Brown, H. and Lee, H. (2015). Teaching by Principles. An Interactive Approach to Language Pedagogy. Upper Saddle River: Pearson Education.

Eastman, J.K. (1991). "Why Listening to English Is Difficult for Spanish Students", in Revista Alicantina de Estudios Ingleses 4: 49-64.

Faber Benítez, P. and Jiménez Hurtado, C. (2004). Traducción, Lenguaje y Cognición. Granada: Comares.

Feyten, C. (1991). "The Power of Listening Ability: An Overlook Dimension in Language Acquisition", in The Modern Language Journal 75 (2): 173-180.

Flowerdew, J. and Miller, L. (2005). Second language listening: theory and practice. Cambridge: Cambridge University Press.

Gile, D. (1992). "Basic theoretical components in interpreter and translator training", in C. Dollerup and A. Loddegaard (eds.), Teaching translation and interpreting: training, talent and experience, Amsterdam: John Benjamins, 185-194.

Gile, D. (2009). Basic Concepts and Models for Interpreter and Translator Training. Revised edition. Amsterdam: John Benjamins.

Goh, Christine C.M. (2000). "A cognitive perspective on language learners' listening comprehension problems", in System 28: 55-75. 
Graham, S. (2006). "Listening comprehension: the learners' perspective", in System 34: 165-182. Iglesias Fernández, E. (2007). La didáctica de la interpretación de conferencias. Teoría y práctica. Granada: Comares.

Iliescu Gheorghiu, C. (2004). Introducción a la interpretación. La modalidad consecutiva. Alicante: Publicaciones de la Universidad de Alicante.

Jiménez Ivars, A. (1999). La traducción a la vista. Un análisis descriptivo. PhD Dissertation. Castellón: Universitat Jaume I.

Jones Vogety, A. (1998). "Listening Comprehension Anxiety: Students' Reported Sources and Solutions", in Foreign Language Annals 31 (1): 67-80.

Kurita, T. (2012). Issues in social listening comprehension and the pedagogical implications. Accents Asia 5 (1): 30-44.

Madrid, D. and McLaren, N. (1995). Didactic procedures for TEFL. Valladolid: La Calesa.

Martin, A. (2015). "La formación en interpretación en España: pasado y presente", en MonTI Special Issue 2: 87-110.

Mendelsohn, D.J. (1994). Learning to listen. A strategy-based approach for the second-language learner. San Diego: Dominie Press.

Meskill, C. (1996). "Listening Skills Development Through Multimedia", in Journal of Educational and Hypermedia 5 (2): 179-201.

Oxford, R. (1993). "Research update on teaching L2 listening", in System 21 (2): 205-211.

Prieto Velasco, J.A. (2012). "La implantación de los nuevos títulos de Grado en Traducción e Interpretación en la universidad española", in P. Ordóñez López y T. Conde (eds.), Estudios de Traducción e Interpretación: Perspectivas Transversales. Vol. I, Col·lecció Estudis sobre la Traducció 18. Publicaciones de la Universitat Jaume I.

Renandya, Willy A. and Farrel, Thomas S.C. (2011). "Teacher, the tape is too fast!' Extensive listening in ELT", in ELT Journal 65 (1): 52-59.

Rivers, W. M. (1981). Teaching foreign language skills. Chicago: University of Chicago Press ( $2^{\text {nd }}$ edition).

Rost, M. (1994). Introducing listening. London: Penguin English.

Rost, M. (2006). "Areas of research that influence L2 listening instruction”, in E. Usó Juan and A. Martínez Flor (eds.), Current trends in the development and teaching of the four language skills. Berlin: Walter de Greyter.

Santamaría Ciordia, L. (2015). Manual de buenas prácticas docentes para la formación del intérprete de conferencias. Valladolid: Universidad de Valladolid.

Thompson, I. (1995). "Assessment of second/foreign language listening comprehension", in D.J. Mendelsohn and J. Rubin (eds.), A Guide for the Teaching of Second Language Teaching. San Diego: Dominie Press.

Underwood, M. (1989). Teaching listening. Harlow (Essex): Longman.

Ur, P. (1984). Teaching Listening Comprehension. Cambridge: Cambridge University Press.

Vandergrift, L. (1999). "Facilitating second language listening comprehension: acquiring successful strategies", in ELT Journal 53 (3): 168-176.

Vandergrift, L. (2007). "Recent developments in second and foreign language listening comprehension research", in Language Teaching 40: 191-210.

Vandergrift, L. and Goh, C. (2012). Teaching and Learning Second Language Listening. Metacognition in Action. New York and London: Routledge.

Wilcox Peterson, P. (2001). "Skills and Strategies for Proficient Listening", in M. Celce-Murcia (eds.), Teaching English as a Foreign or Second Language. Boston: Heinle \& Heinle Publishers $\left(3^{\text {rd }}\right.$ edition). 